\title{
ROCK MASS RATING AND FEASIBILITY ASSESSMENT OF KARST CAVE GEO-ECOTOURISM IN TANJUNGSARI DISTRICT, GUNUNGKIDUL REGENCY, YOGYAKARTA SPECIAL REGION, INDONESIA
}

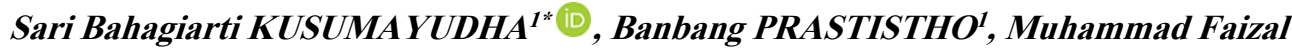 \\ ZAKARIA ${ }^{2}$ (i), Istiana RAHATMA WATH ${ }^{\text {(D) }}$, Tuti SETYANINGRUM+
}

DOI: 10.21163/GT_2021.162.05

\begin{abstract}
:
Tanjungsari district, Gunungkidul Regency, Yogyakarta Special Territory, is located in the karst geopark area of Gunungsewu, Indonesia. The area is geologically constituted of cavernous limestones, characterized by the existence of subsurface drainage. Since the Gunungsewu area was declared as one of the Unesco Global Geoparks in 2015, the tourism sector of this region has propagated rapidly. Tanjungsari district does not like to be left behind in developing the tourism sector. There are several caves in the district that have the potential to be developed for cave tourism, including Bentar Cave, Cabe Cave, Grengseng Cave, Pakubon Cave, and Tritis Cave, which have their uniqueness and attractiveness in terms of exokarst, endokarst, and legends. The development of these potential sites is expected able to improve the economic sector and welfare of the surrounding community. For the caves in Tanjungsari district competitive, the concept of development must be different from that of other places, it is cave geo-ecotourism. In connection with the matters mentioned above, studies and assessments applying engineering geological, social-economical, and agricultural investigations were conducted to explore the potential and feasibility of cave geoecotourism in the Tanjungsari area. Based on the application of cave rock mass rating (CRMR), Bentar Cave has a total score of 69 (Fair), Cabe Cave $=75$ (Good), Grengseng Cave = 47 (Poor), Pakubon Cave $=81$ (Good), and Tritis Cave $=79$ (Good). The results of this study indicate that Bentar Cave has a value of 63.3\%, Cabe Cave 50\%, Grengseng Cave 66.7\%, Pakubon Cave 63.3\%, and Tritis Cave $73.3 \%$ feasibility or readiness if it will be developed as a geo-eco-cave tourism.
\end{abstract}

Key-words: karst, geo eco-tourism, cave, rock mass rating

\section{INTRODUCTION}

Tanjungsari district, Gunungkidul Regency, Yogyakarta Special Territory, is located in the karst geopark area of Gunungsewu, Indonesia. The area is geologically constituted of cavernous limestones, characterized by the existence of subsurface drainage. Since the Gunungsewu area was declared as one of the Unesco Global Geoparks in 2015, the tourism Tanjungsari District belongs to the Gunungkidul Regency, Yogyakarta Special Territory, Indonesia (Fig. 1), with an area of 71.63 square kilometers. The landform shows karst topography, apart of the Gunungsewu mountains, sloping varies from 5\% to more than 40\%, and at an altitude between 100 - 300 meters above sea level. Karst landscape of Tanjungsari area is characterized by subsurface drainage bringing about it subjected to water shortage. In the year 2015, the Gunungsewu has been designated as one of the Global Geopark areas by UNESCO (Kusumayudha, 2018). Since Gunungsewu pointed as Unesco Global Geopark (UGG), the tourism sector is growing rapidly everywhere.

\footnotetext{
${ }^{1}$ Geological Engineering Dept., Univ. Pembangunan Nasional Veteran Yogyakarta, saribk@upnyk.ac.id *, Bambang.prastistho@gmail.com

${ }^{2}$ Geophysical Engineering Dept., Univ. Pembangunan Nasional Veteran Yogyakarta, mfaizal@upnyk.ac.id

${ }^{3}$ Management Dept., Univ. Pembangunan Nasional Veteran Yogyakarta, rahatmawati@gmail.com

${ }^{4}$ Agrotechnology Dept., Univ. Pembangunan Nasional Veteran Yogyakarta, Setyaningrumtuti@gmail.com
} 
Realizing this condition, Tanjungsari District doesn't want to be left behind, it likes to improve its natural potential to be optimally made use for tourism development (Kusumayudha, et.al, 2020). There are five caves in the Tanjungsari district, that expected can be developed as tourist destinations, namely Bentar Cave, Cabe Cave, Grengseng Cave, Pakubon Cave, and Tritis Cave. These caves have unique ornaments, including stalactites and stalagmites, as well as interesting legends, but have not been well exploited and invented yet (Anoname, 2018). In order to develop cave tourism that can be used as a mainstay and superior area for the region, it is necessary to explore and inventory its uniqueness which is different from those of other places, so that they are able to compete with other cave tourism objects that have already developed (Puspitasari \& Rahatmawati, 2017).

Related to the plan of tourism development, there is a relatively new concept of tourism, called geotourism, a model of tourism which emphasizes on geology and geomorphology as the basis of fostering sustainable tourism development (Dowling, 2013). It differs from ecotourism, that is described as about uniting conservation, communities, and sustainable travel (Ruda, 2016). This means that those who implement, participate in and market ecotourism activities should concidering some principles, they are minimizing physical, social, behavioral, and psychological impacts, and developing environmental, cultural awareness and respect (https://notaclueadventures.com/2015/03/blog/ ecotourism-vs-geotourism/). In terms of Geoecotourism, of course it is the combination of the two concepts. Tanjungsari is assumed to have the potency of adopting these concepts in developing its tourism (Kusumayudha, et.al., 2020). In order to develop the area to be a different and sophisticated tourism destination, Tanjungsari needs to apply geo-ecotourism. Based on the backgrounds mentioned above, it is necessary to conduct a research with the objectives to assess the potential and feasibility of karst cave geo-ecotourism in Tanjungsari district based on engineering geological assessments, including geomorphological and lithological mapping, rock mass rating to determine the cave bearing capacity, and socialeconomical-agricultural evaluation.

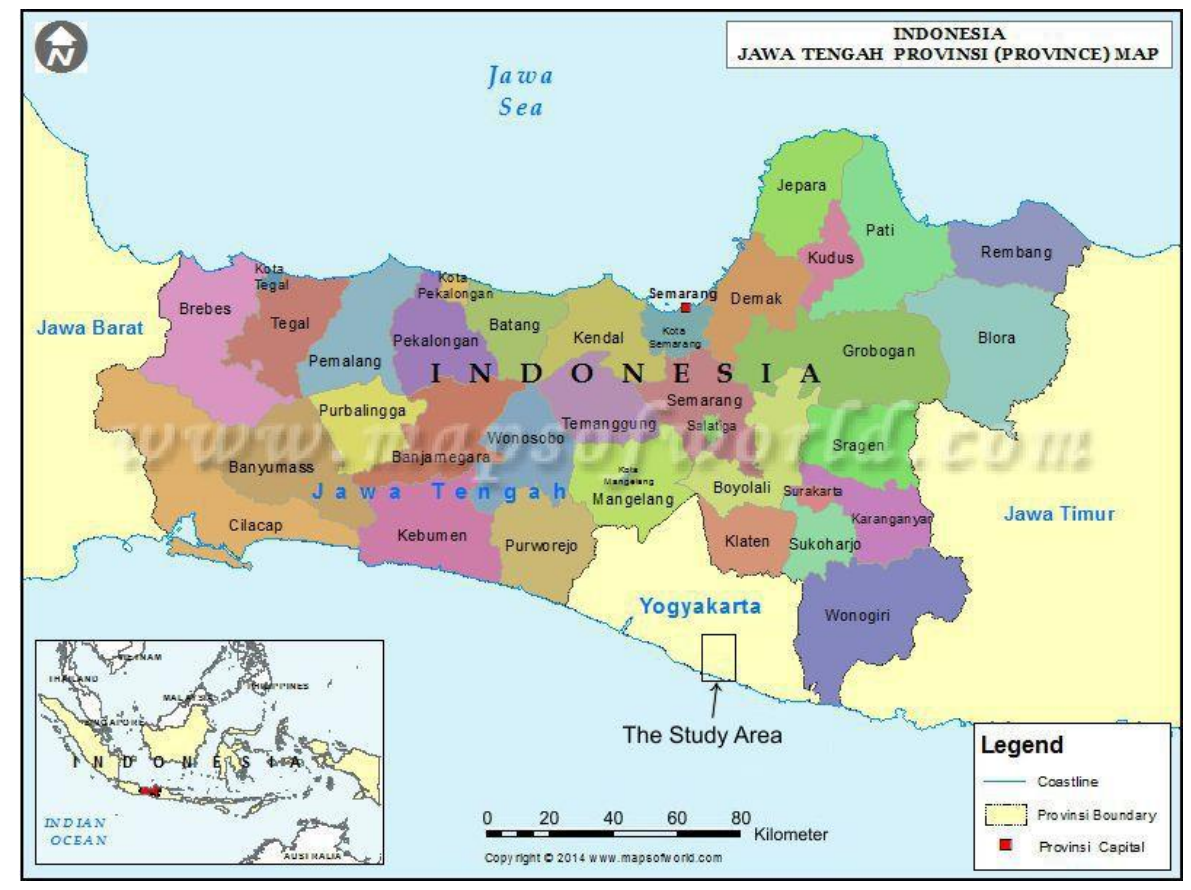

Fig. 1. Location of the Study Area (www.mapsofworld.com/indonesia/provinces/jawa-tengah.html). 


\section{STUDY AREA}

\subsection{Geology}

Physiographically, Tanjungsari district is situated in the Gunungsewu sub-zone of the Southern Mountains of Central Java - East Java (Van Bemmelen, 1949). The Gunungsewu sub-zone is characterized by karst topography with conical and sigmoid hills, showing axis orientation of westeast, with a height difference of $10 \mathrm{~m}-100 \mathrm{~m}$, comprises about 45,000 small and large hills of $50 \mathrm{~m}$ - 300 m diameter (Kusumayudha, 2005).
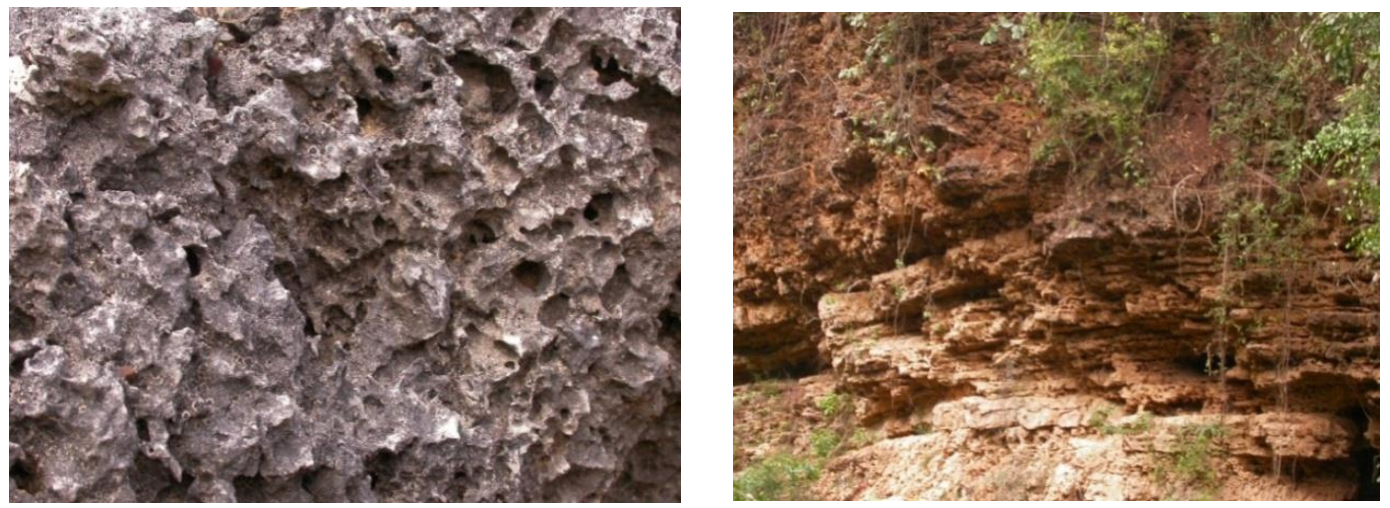

Fig. 2. Reef limestone (left) and bedded limestone (right) (Kusumayudha, et.al, 2020).

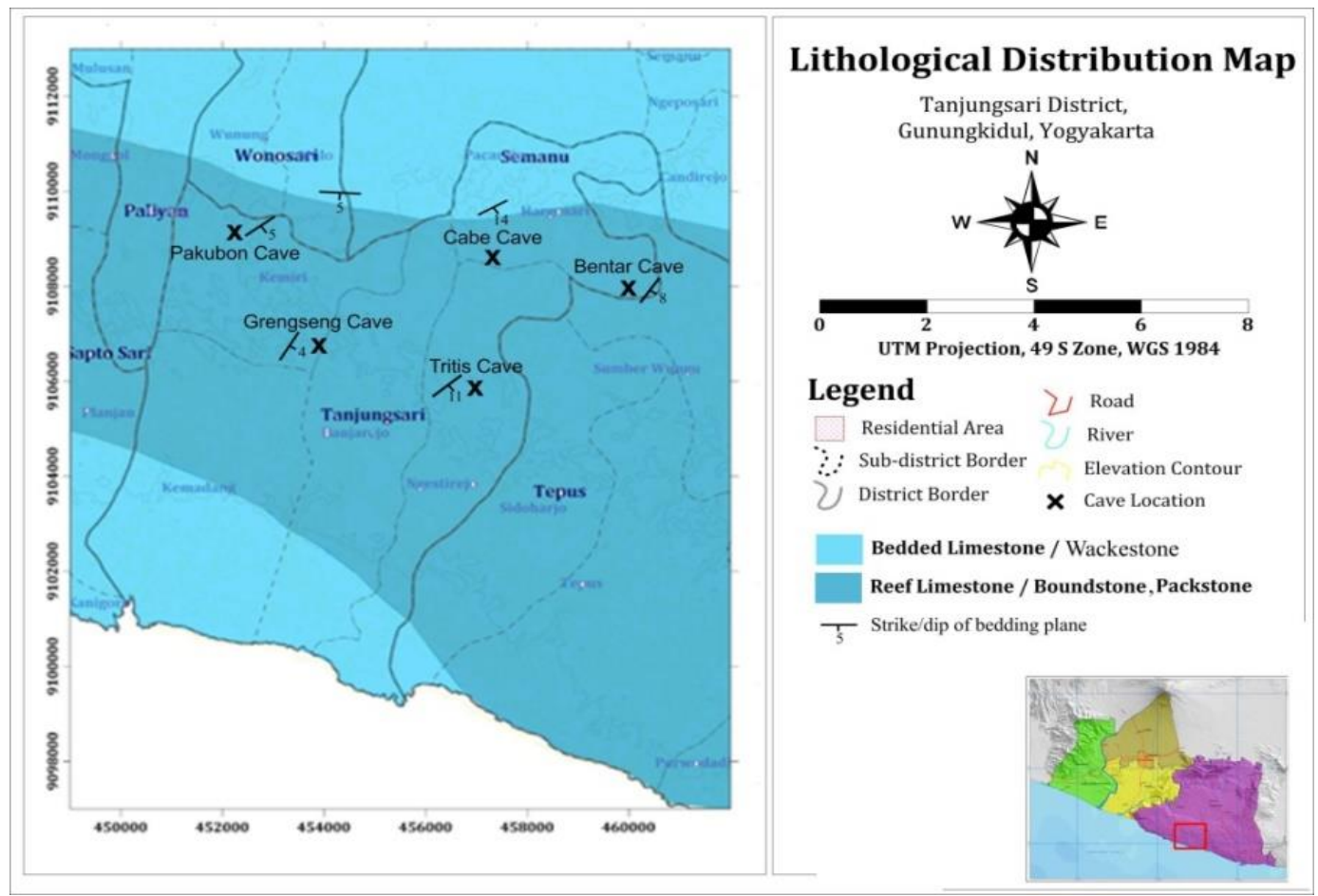

Fig. 3. Lithological distribution of the Tanjungsari and surrounding area (Kusumayudha, et.al, 2020, updated). 
The Gunungsewu karst area is mainly occupied by limestones of the Wonosari Formation, which is generally presenting karstification, and in some places showing calichification (Kusumayudha, 2002). In the basement of Wonosari Formation there exist some lithologic units, from the oldest to the youngest are tuffaceous sandstones of Semilir Formation, volcanic rock consisting of breccias, and lava of Nglanggran Formation, marl of the Sambipitu Formation, and sandy-tuff limestones of the Oyo Formation. Gunungsewu limestone was deposited in the middle Miocene to late Miocene (Suyoto, 1994).

Geomorphologically, the study area displays a hilly karst topography, with a height difference of $10 \mathrm{~m}-30 \mathrm{~m}$, and the hills diameter ranges from $50 \mathrm{~m}-200 \mathrm{~m}$. Macro karst is found in the form of conical to dome-shaped hills, dolines, uvalas, and locvas, while micro karst and lapies which classified as exokarst are also found in the study area.

Lithology in the study area predominantly comprises limestones of the Wonosari Formation, deposited from the middle Miocene to the late Miocene epoch. There are two (2) lithofacieses of the limestone included in boundstone and packstone of reef limestone, and wackestone of bedded limestone (Fig. 2).

The limestones have undergone karstification, entering in the maturity stage, marked by the intensiveness of the carbonate dissolution process, resulting in caves with various ornaments such as stalactites, stalagmites, cinterflags, and flowstones. The distribution of the lithofacies is relatively northwest - southeast, with geological structure shows a homoclinic with an inclination of less than $15^{\circ}$, to the south and southwest (Fig. 3).

\subsection{Caves, Underground Flows, and Hydrogeology}

In the Gunungsewu area, around 460 karst caves were identified, 5 (five) of which are located in the study area, including Bentar Cave, Cabe Cave, Grengseng Cave, Pakubon Cave, and Tritis Cave. Many of the caves are fed by underground rivers, as the main drainage of the Gunungsewu area, and generally discharge to the Indian Ocean. The flow direction of the underground channels is influenced by the pattern of crack structures, and the dip slope of the limestone beddings (Kusumayudha \& Santoso, 1998). One of the main subsurface rivers in the Gunungsewu area is River Bribin (Kusumayudha, 2002).

River Bribin is located in the northern part of the study area, with a flow rate reaching 900 1/sec (Kusumayudha, 2002, 2005). The catchment area of River Bribin is in the Ponjong district, Bedoyo district, and surrounding areas. The streams that were originally on the surface, submerge underground through the Songgilap Cave (Kusumayudha, 2002, 2005). The Bribin flow discharges to the Baron Bay through a karst spring with the rate of $20,000 \mathrm{l} / \mathrm{sec}$ in the peak of the rainy season (Kusumayudha, 2005).

The study area hydrogeologically includes in the Wonosari - Baron subsystem, which is characterized by surface runoff that turns into subsurface flow, the presence of free aquifers and perched aquifer with a thickness of $100-400 \mathrm{~m}$, discharge through an underground river estuary with an average discharge of $79001 / \mathrm{sec}$ (Kusumayudha, 2002, 2005).

\subsection{Culture, Agriculture, and Economics Values}

Culture is one of the characteristics that can distinguish one area from another. Tanjungsari which includes in the Gunungsewu karst area has a unique, rare culture and needs to be preserved. This area has various kinds of cultural heritage, including historical heritages in some caves. The caves have proven to be the center of past activities. In these caves are found relics of the past, and therefore they are called Archeological Caves (Kusumayudha, et.al, 2020). Caves of Tanjungsari that included in archaeological caves are Grengseng Cave and Pakubon Cave. The cultural potential also involves traditional dancing, called jathilan, which expressing heroic soldiers of riding horse. The horce in this dancing is made of woven bamboo, or cow scalp. 
From an agricultural aspect, in the study area, especially of surrounding the caves, there are very potential for empon-empon plants (spice plants, including ginger, turmeric, gatangal, and curcuma). Empon-empon are good plants commodity to be cultivated because people always need it for various purposes. They are rhizomes used as traditional ingredients, and commonly consumed for conventional medicine and cooking spices. Some of the benefits of empon-empon include: as raw material for medicines and herbal medicine, food and beverage industry cooking ingredients, traditional body care ingredients, cosmetics for beauty care, dyes, and for their essential oils. (Cahyadi, 2017). The price is quite high. By cultivating empon-empon, it is hoped that people in the Tanjungsari sub-district can support their economics, by selling empon-empon products either in fresh or processed form.

Another agricultural potential of the Tanjungsari district is cassava plants. In this area, cassava is produced in quantity that exceeds the needs of the local community. Therefore, it is necessary to diversify the handling of cassava so that it can be processed into various snack foods. The local community has processed cassava into various crispies, crackers, chips, and also cassava flour (mokaf). With this mokaf they create a variety of culinary variations, including brownies, fried shrimp with mokaf, and cendol (colourful shaved-ice desserts).

\section{DATA AND METHODS}

The research was applying analytical, descriptive and surveys of engineering geological investigation methods, utilized two kinds of data, both secondary includes a variety of information from the results of existing research and studies, and primary data that were obtained through surveys, investigations, and field mapping. Activities have been done including geomorphological mapping, lithological - stratigraphical identifications, and geologic structural analyses. While cave tracking had been done to map and inventory the distribution of cave passages, uniqueness, and speleothems. Rock sampling was also carried out for petrological assessment, as well as for rock properties testing. The method used to determine the strength of the rock is unconfined compressive strength (UCS). Cultural and agricultural surveys were also done to complete the study.

In order to assess the significance of the geological and geomorphological sites for cave geotourism targets, the concept of geomorphosites is appropriate to be applied (Kubalikova, 2013). Some assessment was carried out for geotourism purposes, from several perspectives, with an emphasis on using scientific, cultural and economics parameters (Table 1). The results of the assessment can serve as a basis for appropriate use of geoheritage, its management, and identification of geotourism potential of the study area (Kubalikova, 2013).

Table 1.

Assessment criteria according to Reynard, et al. (2007), (Kubalikova, 2013), modified.

\begin{tabular}{ll}
\hline Value & Criteria \\
\hline scientific values & integrity; representativeness; paleogeographical value; rareness \\
ecological values & ecological impact; protected species \\
aesthetic values & number of viewpoints; landscape/scanic beauty \\
cultural values & religious importance; historical importance; artistic importance \\
social-economic values & economic products; human resource support, agricultural support \\
\hline
\end{tabular}

To evaluate the mentioned geomorphosite assessment methods in terms of suitability for geotourism purposes, each of the criteria related to the parameters is then given a value. The value is =1, when the method considers the criterion, 0.5 if the method partly considers the criterion, and 0 , for the method does not consider the criterion (Kubalikova, 2013). This study was also completed with a geomechanical assessment for the limestone comprising the cave, mentioned RMR (Rock 
Mass Rating), roof thickness, and source of vibration. In this case, the cave is assumed to be a tunnel, to be invented their bearing capacity for tourism.

RMR was developed by Bieniawski in 1973 (Franklin \& Dussault, 1989), utilizes the following six rock mass parameters: 1) Uniaxial compressive strength (UCS) of intact rock material; 2) Rock quality designation (RQD); 3) Spacing of discontinuities; 4) Condition of discontinuities, given as 4a Length, persistence 4b Separation 4c Smoothness 4d Infilling 4e Alteration/weathering; 5) Groundwater conditions (Table 2). The classification of RQD is using Table 2. After an assessment was carried out based on Table 3, the classification of the rock mass quality was then determined using Table 4.

Table 2.

RQD Classification.

\begin{tabular}{lllll}
\hline RQD & $<25 \%$ & $25-50 \%$ & $51-75 \%$ & $76-90 \%$ \\
\hline Rock Mass Classification & Very poor & Poor & Fair & Good \\
\hline
\end{tabular}

Table 3.

Parameters and values of RMR (Bieniawski, 1973 vide Franklin \& Dussault, 1989).

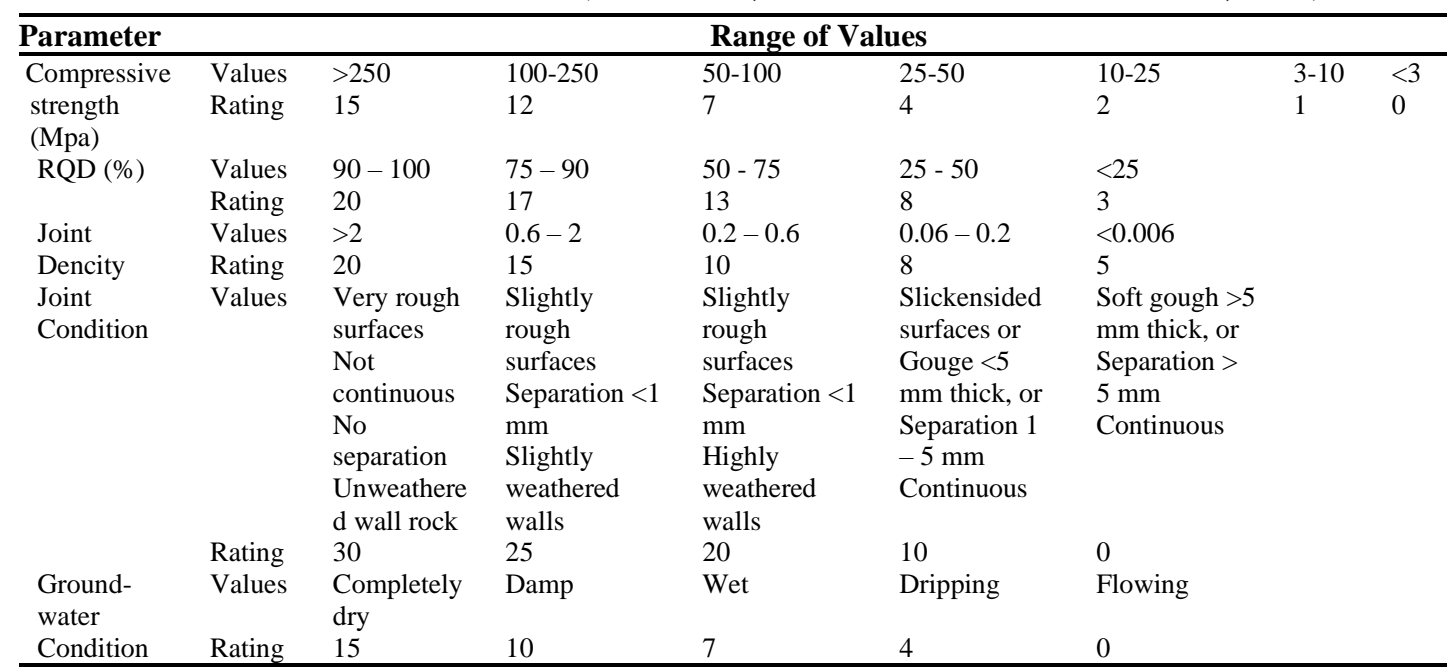

Table 4.

\section{Geomechanics Classification of Rock Masses \\ (Bieniawski, 1973, vide Franklin \& Dussault, 1989).}

\begin{tabular}{llc}
\hline \multicolumn{1}{c}{ Class } & \multicolumn{1}{c}{ Discription of Rock Mass } & RMR (Sum of Rating Increments) \\
\hline I & Very Good Rock & $81-100$ \\
II & Good Rock & $61-80$ \\
III & Fair Rock & $41-60$ \\
IV & Poor Rock & $21-40$ \\
V & Very Poor Rock & $>20$ \\
\hline
\end{tabular}

In this study the Bieniawski RMR method was modified by adding 2 other parameters, namely 1) the thickness of the cave roof, and 2) the source of vibrations/shocks. This method is then used to study the feasibility of the cave, especially in relation to the carrying capacity of the cave if it is developed as a tourist visit, and the risk of cave collapse, from a geotechnical aspect. The values for the two additional parameters are as follows (Table 5): 
Table 5.

Addition Parameters and their Values and Rating.

\begin{tabular}{lllllll}
\hline Parameter & \multicolumn{5}{c}{ Range of Values } \\
\hline Cave roof thickness (m) & Values & $<1$ & $1-5$ & $5-10$ & $10-20$ & $>20$ \\
& Rating & 0 & 5 & 10 & 15 & 20 \\
Distance to the source of & Values & $<50$ & $50-100$ & $100-200$ & $200-500$ & $>500$ \\
vibration (m) & Rating & 0 & 5 & 10 & 15 & 20 \\
\hline
\end{tabular}

After being modified, the scoring for cave rock mass rating (CRMR) to be as follows (Table 6):

Geotechnical Classification of the Cave Feasibility for Tourism.

Table 6.

\begin{tabular}{ccccc}
\hline Class & $\begin{array}{c}\text { Description of Rock } \\
\text { Mass }\end{array}$ & \multicolumn{2}{c}{ Sum of Rating Increments } & Geotechnical Feasibility \\
& $\boldsymbol{R M R}$ & $\boldsymbol{C R M R}$ & \\
\hline I & Very Good Rock & $81-100$ & $91-120$ & Very Good \\
II & Good Rock & $61-80$ & $71-90$ & Good \\
III & Fair Rock & $41-60$ & $51-70$ & Fair \\
IV & Poor Rock & $21-40$ & $31-50$ & Poor \\
V & Very Poor Rock & $<20$ & $<30$ & Very Poor \\
\hline
\end{tabular}

This method was then used to assess the feasibility of the cave when they are intended to be used for tourism destination from the engineering geological point of view.

\section{RESULTS AND DISCUSSIONS}

\subsection{Cave Geo-Ecotourism Feassability of Tanjungsari Area}

Based on potencies investigation and assessment on the caves of Tanjungsari District for geo eco-tourism, it can be described as the following.

\section{a. Bentar Cave}

The Bentar Cave is located in Jrakah hamlet, Hargosari village, easily accessible, the road to the cave has been adequately constructed by the local community. It has an extraordinarily beautiful charm, although its morphology can be classified as a vertical cave (Fig. 4).
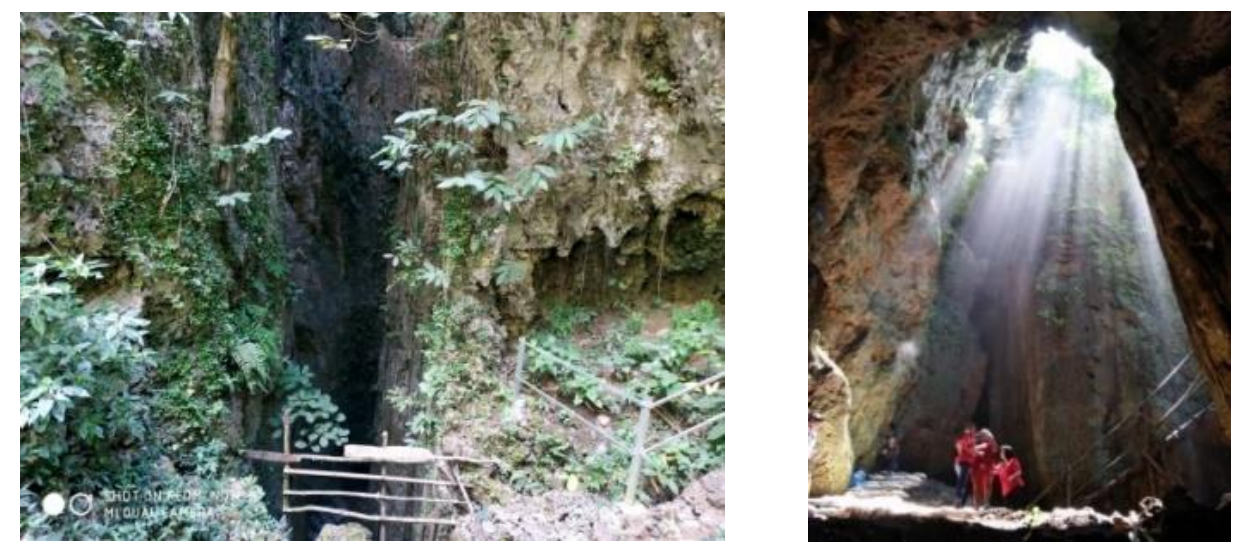

Fig. 4. Vertical shaft (left) and the window of the light (right) of the Bentar Cave (Kusumayudha, et.al, 2020). 
The cave exists due to the control of fractures dissected the limestone, which then interacts with meteoric water to form a vertical shaft. Inside the cave, there is a natural window on the roof of the cave, causing light from outside to be able to penetrate the cave. This place is very interesting as a means of photography to display breakthrough images of light (Fig. 4).

This cave is interesting and challenging, especially for adventure-loving tourists, because of the vertical passageways. Young tourists have often visited to enjoy the challenges in the cave. However, for general tourists, it needs to be facilitated with artificial stairs, so that they are helped when they want to enter and explore the Bentar Cave. This cave is divided into several rooms, namely the left side room, the living room, and the right-side room. The left side room is about 20 meters from the living room, then go down the stairs about 8 meters. This space is 30 meters in diameter with a height of 50 meters and there is an air hole above. In this room their live bats, frogs, and grasshoppers. Stalactites and stalagmites of the cave are still active.

From an engineering geological point of view, Bentar Cave has a fairly good feasibility, due to the thickness of the cave roof is quite thick, the depth of the cave reaches $>10 \mathrm{~m}$ from the surface, joint spacing in general is $>2$ and is cemented with calcite and is overgrown with cave speleothems. Thus, the risk of collapse is small. To support the construction of Bentar Cave as a tourist attraction, tracing the cave has been carried out with the results as shown in Fig. 5.

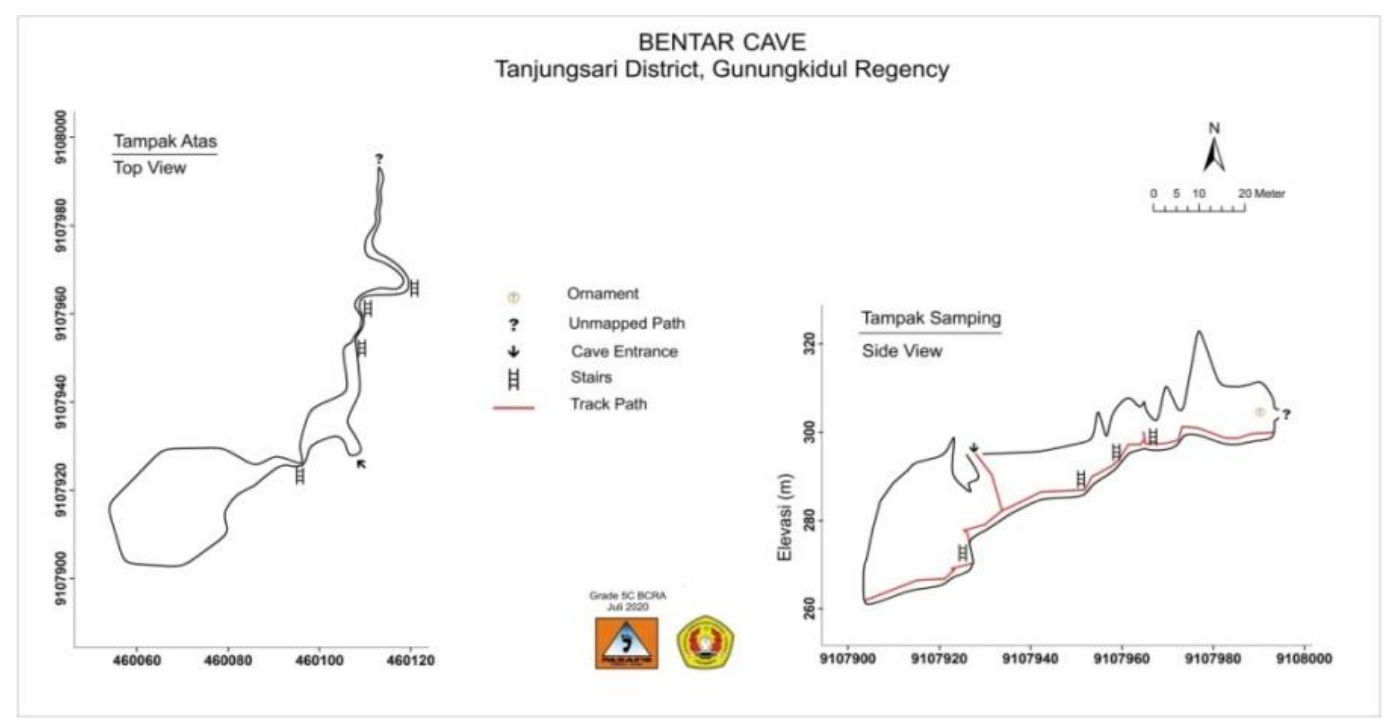

Fig. 5. Situation map of Cave Bentar (Kusumayudha, et.al, 2020).

Preparations made by the local community for the development of cave tourism include forming a management forum of tourism conscious community, namely Pokdarwis Swargaloka. The group has built 20-meter-high stairs for visitors. The community also tries to support the development of the cave with culinary delights made from local ingredients, such as cassava, papaya leaves, and empon-empon. Plants that grow around the cave are perennials, cassava, and empon-empon plants that still need an arrangement.

\section{b. Cabe Cave}

Cabe Cave is located in Timunsari hamlet, Hargosari village, situated on a hill. The accessibility of this cave is still inadequate to open immediately as a tourist attraction, because to reach it, visitors have to walk hike up more than $500 \mathrm{~m}$ through rocky paths. The mouth of the cave is relatively narrow, only sufficient for one person to enter. However, in the cave, there is a wide enough hallway and space. Inside the cave, there are ornaments in the form of stalactites, stalagmites, and pillars (Fig. 6). 
The Cabe Cave belongs to cultural heritage, because there a historical inscription has been found in this cave, called Nganjatan I and II inscriptions. They are bronze inscriptions with a length of $48 \mathrm{~cm}$, a width of $18 \mathrm{~cm}$, and a thickness of $0.2 \mathrm{~cm}$ with ancient Javanese script consisting of 12 lines of writing. By the way, this cave has not been well explored because the local people still protect it, considering that this cave has historical recollections, even though this cave actually has a beautiful charm of stalactites and stalagmites. It is hoped that this cave can be developed as a cultural heritage cave.

From the feasibility aspect of engineering geology, it is estimated that this cave has a small risk of collapse, because the roof of the cave is quite thick, with a solid density of $0.6 \mathrm{~m}$, the fractures are generally open but filled with recrystallization of calcite. On the other hand, the plants that grow around the cave are generally wild plants, yams, and nuts. There has been no adequate arrangement from the aspect of agriculture, human resource support is still minimal. Pokdarwis (tourism conscious community) has been formed, but it has not worked optimally.
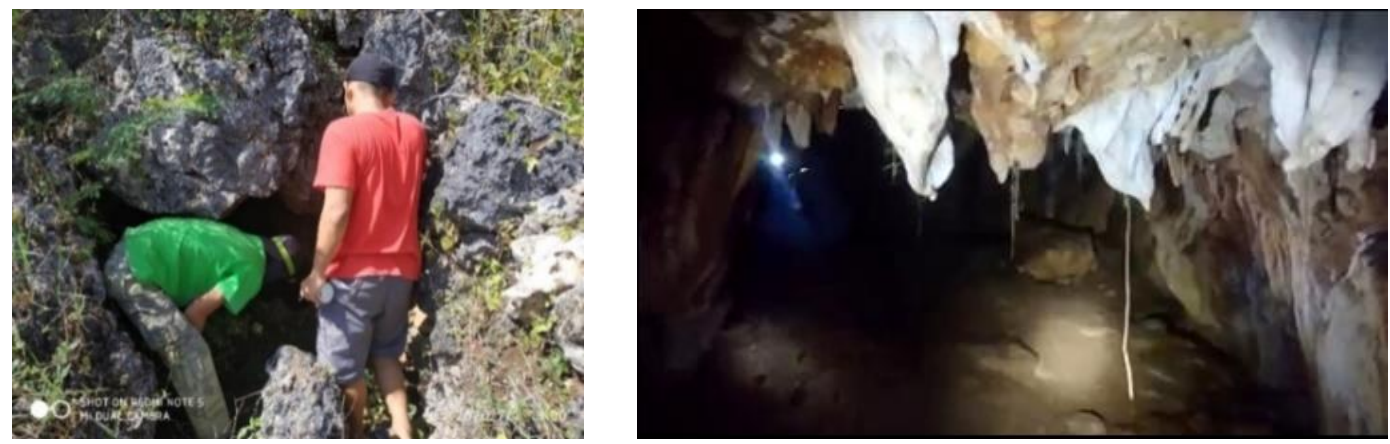

Fig 6. Environmental situation of cave Cabe (left), the mouth of Cave Cabe (right).

\section{c. Grengseng Cave}

The Grengseng Cave is located in Kelor Lor hamlet, Kemadang village. The cave entrance is close to a preliminary school, residential area, and very close to an inter-village road. The cave inside is quite wide, there are various ornaments of stalactites and stalagmites, and pillars (Fig. 7). According to residents around this cave, the passage of the cave may penetrate to residential areas.

Grengseng Cave has three interconnected entrances. The first entrance is $3,2 \mathrm{~m}$ wide, the second entrance wide: $4,5 \mathrm{~m}$ and the third entrance is $2 \mathrm{~m}$ in width. Unfortunately, the roof thickness of the area of surrounding the first entrance only ranges $2 \mathrm{~m}-3 \mathrm{~m}$, there are many opened cracks and joints, with joint density of about $0.28-0.57 \mathrm{~m}$. The depth of the cave cannot be ascertained yet, but the depth for the oxygen safe reach is approximately $137 \mathrm{~m}$. There are more than 15 rooms in the cave with active stalactites and stalagmites. Inside the cave can be found various animals such as bats, squats, crickets, and worms. According to local history, Grengseng cave had been visited by king Brawijaya (Bhre Kertabumi), the last king of the Majapahit Kingdom, in the 14th century, for meditation (Setyaningrum, et.al., 2020). The situation map is displayed in Fig. 8.

There are various traditional events that routine to be done in Grengseng Cave, namely Sadranan and Rasulan. The events are held once every 35 days, on Friday night, which is believed to be a good day to face the planting period, and harvesting period. The activities are about cleaning the environment of the hamlet.

A series of tourism potentials are offered at Grengseng Cave and its surroundings. It consists of enjoying the sunrise and sunset on the top of Bei hill, exploring the Grengseng cave, visiting a karawitan (Javanis traditional music) studio which at the same time we can play directly with the traditional musicians, visiting mokaf (cassava flour) making, and trying to make mokaf yourself accompanied by a group team, calling on the natural batik-making process and trying to do it, entering the vertical Banteng cave, tracking Banteng Cave, going to Watu Kodok beach, and enjoying the atmosphere at the Bamboo Hill (Setyaningrum, et.al, 2020). The support of human 
resources in this area is good, Pokdarwis has worked enthusiastically, efforts to organize agricultural aspects have started to be made by the local community.
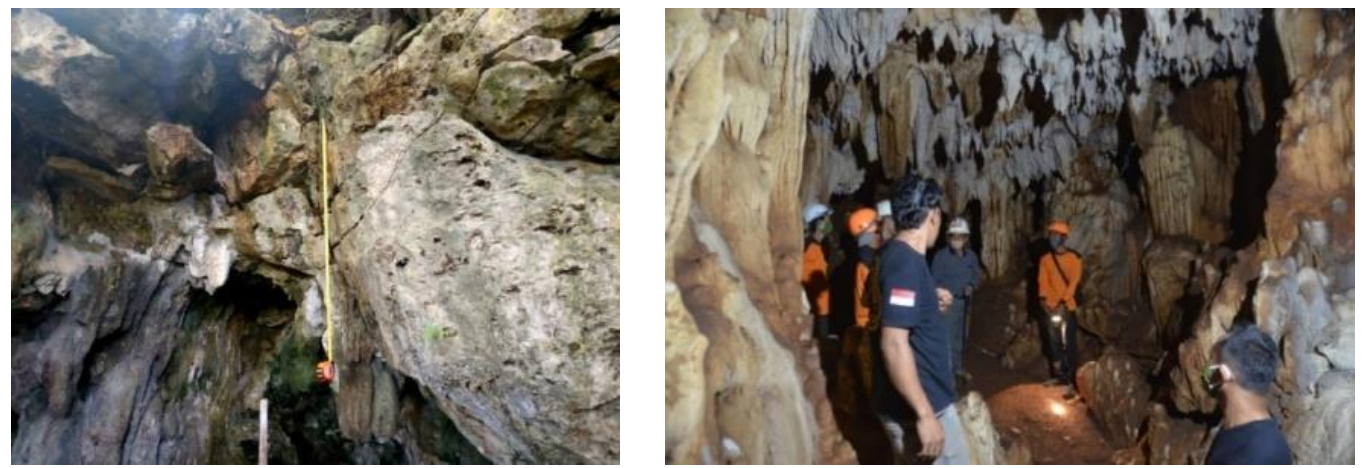

Fig. 7. In side of the Grengseng cave and its ornaments (Kusumayudha, et.al, 2020)

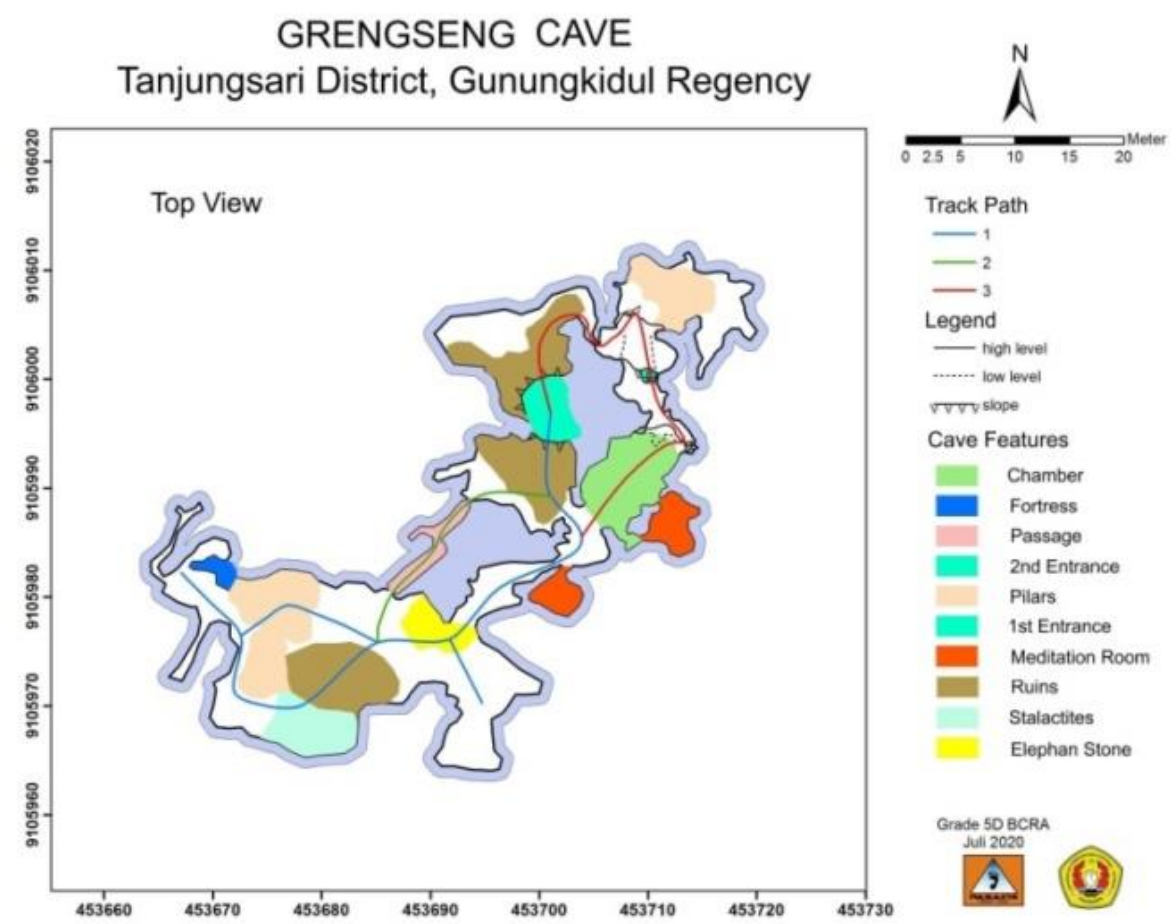

Fig. 8. Situation map of the Grengseng Cave (Kusumayudha, et.al, 2020).

\section{d. Pakubon Cave}

The Pakubon Cave is located at Ngasem hamlet, Kemiri village. To access the cave is very easy, it is close to the Baron beach, about $1 \mathrm{~km}$ distance. With an adequate wide enough road. Although it is intended to be opened as a new tourist destination, but the facilities around the cave are still minimal, including the parking area, and the way to entrance and exit the cave. There is an area for a camping ground or out bond activities, in front of the cave. A relatively large room can be found inside, on the roof, there are stalactites, some of which are relatively big in size and unique in shape, like crystal chandeliers (Fig. 9). There are no stalagmites. This indicates that Pakubon Cave is often traversed by water flows. The situation map of Pakubon Cave is shown in Fig. 10. 

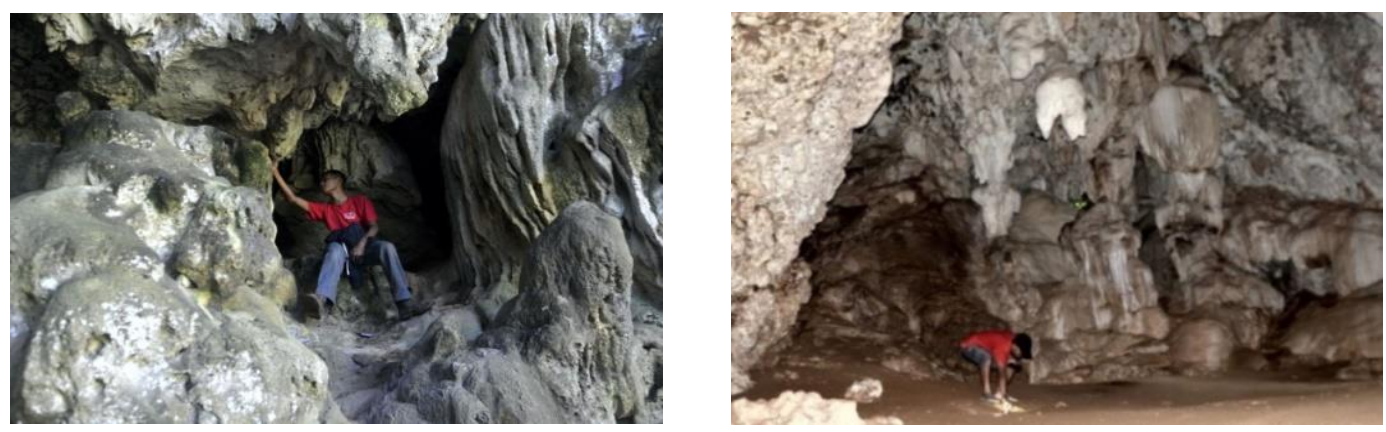

Fig. 9. Inside of the Pakubon Cave, there is a unique form of stalactite: crystal chandelier like (Kusumayudha, et.al, 2020).

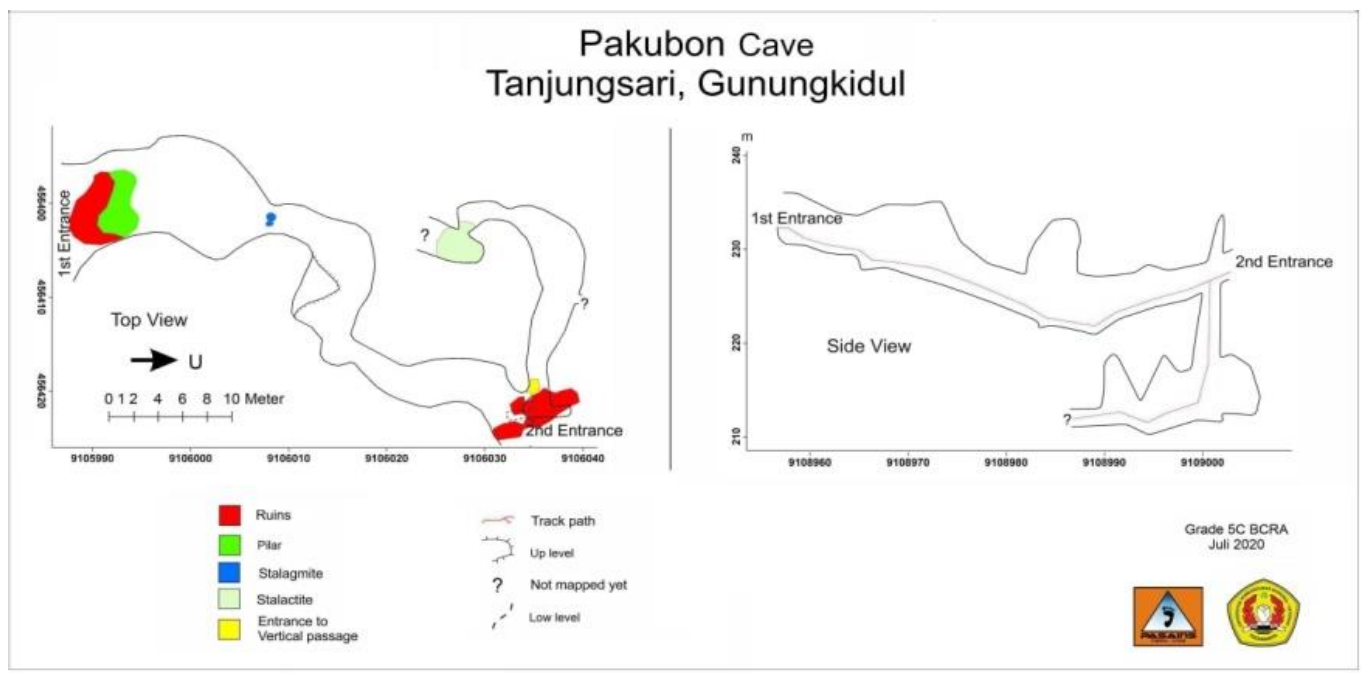

Fig. 10. Situation map of the Pakubon cave. (Kusumayudha, et.al, 2020).

To support Pakubon Cave tours, Ngasem hamlet also contains a cultural, historical, and educational wealth. The cultural wealth has been preserved until today, such as cleaning the lake and the apostles. Inside the Pakubon cave, there are many active stalactites and an interesting panoramic view of the cave walls. The panorama and beauty of Pakubon Cave are also complemented by the presence of calcite crystals, as well as decorative flowstones, cinterflags, some that resemble flowers, and stone carvings. Pakubon Cave can be developed as a natural, cultural and educational tourism object. Although this cave is potential to be developed as geo-ecotourism, but human resource support of this area is not optimal yet. Actually, there is agricultural potential, because various kinds of plants can be cultivated in this area, including teak, cashew, cassava, empon-empon, nuts, and horticulture trees.

\section{e. Tritis Cave}

The Tritis Cave is located in Jaten hamlet, Ngestirejo village. Inside the cave, there are stalagmites and stalactites. This cave is also often used for a ritual or meditation place. There is a lake in front of the cave. The bottom of the lake is covered by sediments with the composition of clay at the top, volcanic ash and silt, and sandy silt at the bottom.

Based on some residents' information, sediments at the bottom of the lake have ever been dredged, intended to make the lake's capacity greater, and the lake's water is expected to be 
increased. Unfortunately, sediment dredging at the bottom of the lake resulted in the lake leaking. Based on infiltration testing using a double ring infiltrometer, the infiltration rate of the sediment that is predominantly composed of silt on the lake ranges $10-13 \mathrm{~cm} / \mathrm{hour}$. This indicates that the relatively water-resistant layer has been lost due to dredging, leaving a relatively permeable layer. Another uniqueness of the Tritis Cave is the discovery of volcanic ash deposit layers near the mouth of the cave (Fig.11).
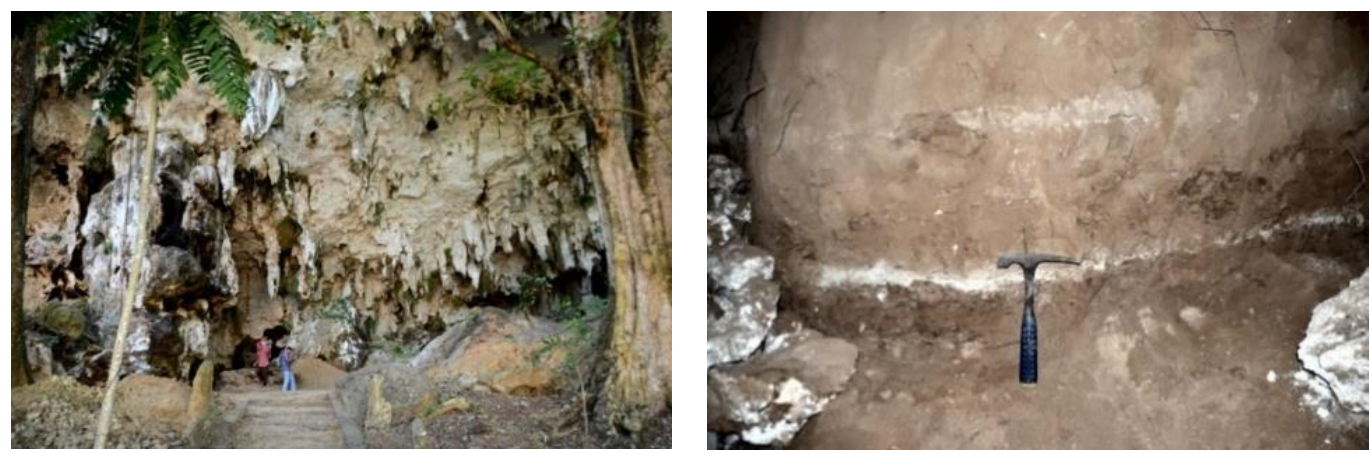

Fig. 11. Cave Tritis entrance (left) and volcanic ash deposit (right) (Kusumayudha, et.al, 2020).

The scenery on the porch of Tritis cave has its own beauty. To support Tritis Cave geoecotourism, the community has planted various decorative plants and local fruits, as well as the presentation of various processed agricultural products. Around the Tritis Cave, cassava is the main commodity developed in the area. Various kinds of processed products can be used as a complement to culinary tours. Planting local fruit, especially srikaya around the tourist area, besides complementing the beauty of the scenery, it also adds to the completeness of biodiversity and can be enjoyed by the fruit. Likewise, planting sunflowers and various other attractive plants increases the beauty of the view on the cave porch.

\subsection{Rock Mass Rating and Feasibility Assessment for Caves Geo Eco-tourism.}

Cave RMR (CRMR) has been carried out to acquire information and indicators about the carrying capacity and safety of the cave if it is developed for tourist visits. The components used in conducting this method are based on the value of RQD (Rock Quality Designation), rock strength, discontinuity spacing, joint conditions, groundwater conditions around the caves, roof thickness, and distance to the source of vibration. The result is as follows (Table 7)

Based on the assessment on the rock masses make up the five caves, using CRMR, the total score of Bentar Cave $=69$ is fair rock category, Cabe Cave $=75$, including in good rock, Grengseng Cave $=47$ classified as poor rock, Cave Pakubon $=81$ categorized as good rock, and Tritis Cave $=$ 79 belongs to good rock as well. Thus, from a geotechnical aspect, the feasibility of Bentar Cave can be categorized as adequate, Grengseng Cave is not feasible, while Cabe Cave, Pakubon Cave, and Tritis Cave are suitable to be developed as tourism objects. With a thin roof and a lot of joints, Grengseng Cave is at risk of collapse.

With this risk, if Grengseng Cave is intended to be developed as a tourist attraction, it is necessary to safeguard the cave, to reduce the risk of collapse, namely by grouting the cracks of the cave roof. However, it is necessary to select cracks to be grouted, in order not significantly to affect speleothem formation and growth.

After finishing the CRMR, an assessment using the method promoted by Kubalikova (2013) was carried out on the five caves of the study area. The assessment was done to find out how much potential and feasibility they would be if they were developed as a karst cave geo eco-tourism. The results of this study can be seen in Table 8 . 
Cave Rock Mass Rating of the Study Area.

Table 7.

\begin{tabular}{|c|c|c|c|c|}
\hline Cave Name & Parameter & Discription & Rating & $\begin{array}{l}\text { Total } \\
\text { Score \& } \\
\text { CRMR } \\
\text { Class }\end{array}$ \\
\hline \multirow[t]{7}{*}{ Bentar } & UCS (Mpa) & 43.12 & 4 & \multirow{7}{*}{$\begin{array}{c}69 \\
(\text { Fair })\end{array}$} \\
\hline & RQD (\%) & $60-70$ & 13 & \\
\hline & Joint Density & 0.5 & 10 & \\
\hline & Joint Condition & $\begin{array}{l}\text { Rough surface, aperture }>10 \mathrm{~mm} \text {, hard } \\
\text { wall rock }\end{array}$ & 15 & \\
\hline & $\begin{array}{l}\text { Groundwater } \\
\text { Condition }\end{array}$ & Wet & 7 & \\
\hline & Cave roof Thickness & $10 m-20 m$ & 15 & \\
\hline & Source of Vibration & Distance to the road $50-100 \mathrm{~m}$ & 5 & \\
\hline \multirow[t]{7}{*}{ Cabe } & UCS (Mpa) & 60.27 & 5 & \multirow{7}{*}{$\begin{array}{c}75 \\
(\text { Good })\end{array}$} \\
\hline & RQD (\%) & $70-90$ & 13 & \\
\hline & Joint Density & 0.6 & 10 & \\
\hline & Joint Condition & $\begin{array}{l}\text { Rough surface, aperture }>10 \mathrm{~mm} \text {, joints } \\
\text { are filled with calcite, hard wall rock }\end{array}$ & 15 & \\
\hline & $\begin{array}{l}\text { Groundwater } \\
\text { Condition }\end{array}$ & Wet & 7 & \\
\hline & Cave roof Thickness & $5 m-10 m$ & 10 & \\
\hline & Source of Vibration & Distance to the road $200-500 \mathrm{~m}$ & 15 & \\
\hline \multirow[t]{7}{*}{ Grengseng } & UCS (Mpa) & 37.68 & 3 & \multirow{7}{*}{$\begin{array}{c}47 \\
\text { (Poor) }\end{array}$} \\
\hline & RQD (\%) & $40 ; 52 ; 62 ; 94$ & 13 & \\
\hline & Joint Density & $0.28-0.57$ & 7 & \\
\hline & Joint Condition & $\begin{array}{l}\text { Openned joint, filled with soil, } 5 \mathrm{~mm}-100 \\
\mathrm{~mm}\end{array}$ & 15 & \\
\hline & $\begin{array}{l}\text { Groundwater } \\
\text { Condition }\end{array}$ & Wet, and dripping & 4 & \\
\hline & Cave roof Thickness & $3-5 \mathrm{~m}$ & 5 & \\
\hline & Source of Vibration & Distance to the road $<50 \mathrm{~m}$ & 0 & \\
\hline \multirow[t]{8}{*}{ Pakubon } & UCS (Mpa) & 46.76 & 4 & \multirow{8}{*}{$\begin{array}{c}81 \\
(\mathrm{Good})\end{array}$} \\
\hline & RQD (\%) & $80-85$ & 17 & \\
\hline & Joint Density & 0.8 & 13 & \\
\hline & Joint Condition & $\begin{array}{l}\text { Rough surface, aperture }>10 \mathrm{~mm} \text {, parts of } \\
\text { which are filled with calcite, hard wall } \\
\text { rock }\end{array}$ & 15 & \\
\hline & Groundwater & Wet & 7 & \\
\hline & Condition & & & \\
\hline & Cave roof Thickness & $5 m-10 m$ & 10 & \\
\hline & Source of Vibration & Distance to the road $200-500 \mathrm{~m}$ & 15 & \\
\hline \multirow[t]{7}{*}{ Tritis } & UCS (Mpa) & 36.11 & 3 & \multirow{7}{*}{$\begin{array}{c}79 \\
\text { (Good) }\end{array}$} \\
\hline & RQD (\%) & $70-80$ & 16 & \\
\hline & Joint Density & $0.55-0.56$ & 10 & \\
\hline & Joint Condition & $\begin{array}{l}\text { Openned joint, filled with calcite, } 10 \mathrm{~mm} \text { - } \\
100 \mathrm{~mm} \text { thick }\end{array}$ & 15 & \\
\hline & $\begin{array}{l}\text { Groundwater } \\
\text { Condition }\end{array}$ & Damp & 10 & \\
\hline & Cave roof Thickness & $5 m-10 m$ & 10 & \\
\hline & Source of Vibration & Distance to the road $200-500 \mathrm{~m}$ & 15 & \\
\hline
\end{tabular}


The whole feasibility assessment of cave geo-ecotourism are as follows.

Table 8.

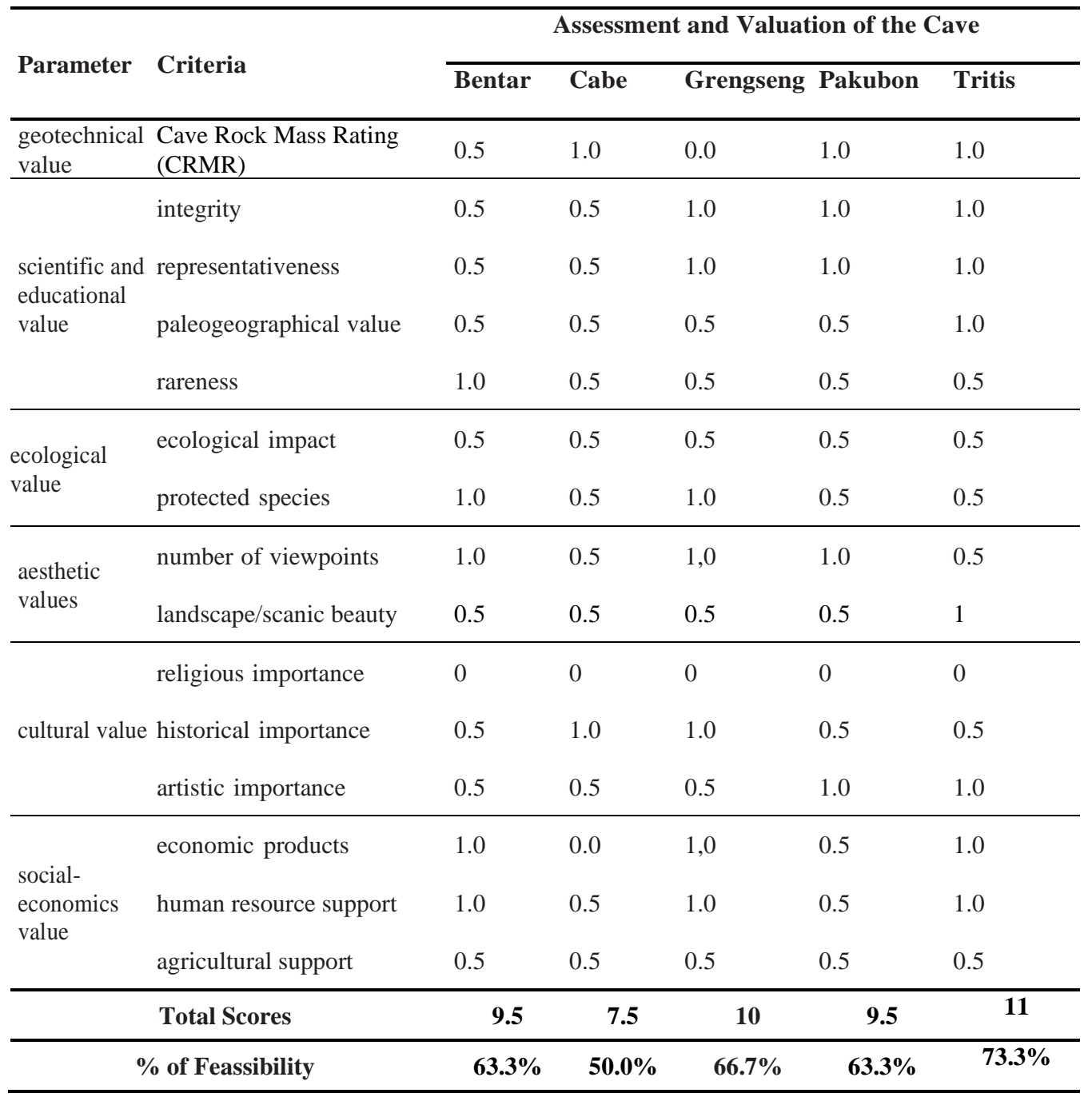

Based on the above study, the results show that Bentar Cave has a value of $63.3 \%$, Cabe Cave 50.0\%, Grengseng Cave 66.7\%, Pakubon Cave 63.3\%, and Tritis Cave $73.3 \%$ feasibility or readiness when they will be developed as cave geo eco-tourism. The five caves have their respective strengths and weaknesses. For this reason, in the future research, it is recommended to conduct a SWOT analysis in order to determine the solutions and to take further action of developing them.

The things that need to be considered at this time for each of the 5 caves are as follows: Bentar Cave is necessary to provide more facilities, Cabe Cave needs to be more open, environmental arrangement, and adds more adequate facilities, Grengseng Cave needs to geotechnical support for the roof of the cave in particular which is around the mouth of the cave, Pakubon Cave needs to improve its facilities and environmental arrangements, while Tritis Cave needs better management, promotion, and creating tourism flow modelling, to identify the fluctuation of tourism stream and its cartographic representation for transport companies (Nistor \& Nicula, 2021). 


\section{CONCLUSIONS}

1. In the Tanjungsari area that is geomorphologically forms a karst topography, composed of reef limestone classified into boundstone and packstone and bedded limestone of wackestone, there are 5 (five) caves with their uniqueness in term of ornaments and history, identified able to be developed to become geo eco-tourism, namely Bentar Cave, Cabe Cave, Grengseng Cave, Pakubon Cave, and Tritis Cave.

2. Based on the application of Cave RMR, Bentar Cave has a total score of 69 (Fair), Cabe Cave total score $=75$ (Good), Grengseng Cave total score $=47$ (Poor), Pakubon Cave total score $=81$ (Good), and Tritis Cave total score $=79$ (Good).

3. Referring to the feasibility assessment using parameters of geotechnical, scientific-educational, ecological, aesthetic, cultural, and social-economic values, Bentar Cave has a total score of 63.3\%, Cabe Cave 50.0\%, Grengseng Cave 66.7\%, Pakubon Cave 63.3\%, and Tritis Cave $73.3 \%$ feasibility or readiness for being developed as cave geo eco-tourism destinations.

4. In general, the 5 caves are potential to be developed as karst cave geo-ecotourism with their own strength and weakness, however, they need to be built, organized, and managed based on the integrated concept of geo-ecotourism which is considering geological and geotechnical, scientific-educational, ecological, aesthetics, cultural, and social-economical values.

\section{ACKNOWLEDGEMENT}

This study was held with funding from the Institute of Research and Community Service of Universitas Pembangunan Nasional Veteran Yogyakarta. In relation to that, the authors express a high appreciation and deep gratitude to the institution for its support in the operation of this study.

\section{R E F E R E N C E S}

Anoname (2018) The statistics of Gunungkidul, Central Statistics Agency of Gunungkidul Regency

Cahyadi, A. (2017) Land resources of the Gunungsewu Karst Area, https://www.researchgate.net/publication/326114734_Sumberdaya_Lahan_Kawasan_Karst_Gunungsewu

Dowling, R.K. (2013) Global Geotourism - An Emerging Form of Sustainable Tourism. Czech Journal of Tourism, 2(2), 59-79. DOI: 10.2478/cjot-2013-0004.

Franklin, J.A. \& Dusseault, M.B. (1989) Rock Engineering, McGraw Hill Publishing Company, New York.

Kubalikova, L. (2013) Geomorphosite assessment for geotourism purposes. Czech Journal of Tourism, 2(2), 80-104. DOI: 10.2478/cjot-2013-0005.

Kusumayudha, S.B. Zakaria, M.F., Prastistho, B., Rahatmawati, I., Setyaningrum T. (2020) The Potencies of Cave Geo-Ecotourism Development in Tanjungsari District, Gunungkidul Regency, Yogyakarta Special Region, LPPM UPN "Veteran" Yogyakarta Conference Series Proceeding on Political and Social $\begin{array}{llllll}\text { Science } & (P S S), & \text { Volume } & 1 \text { Number } & 1 & \text { (2020): }\end{array}$ http://proceeding.researchsynergypress.com/index.php/pss/article/view/208

Kusumayudha, S.B. (2018) Mengenal Hidrogeologi Karst (Introduction to Karst Hydrogeology), penerbit Pohon Cahaya, Yogyakarta

Kusumayudha, S.B. (2005) Karst Hydrogeology and Fractal Geometry of the Gunungsewu Area, Adicita Publisher, Yogyakarta

Kusumayudha, S.B. (2002) The Gunungsewu Hydrogeologic System, Book: Sumberdaya Geologi Daerah Istimewa Yogyakarta dan Jawa Tengah, IAGI, Pengda DIY-Jateng, 128 - 139

Kusumayudha, S.B. \& Santoso, A. (1998) Daerah Aliran Sungai Bawah Tanah di Gunungsewu Berdasarkan Peta Anomali Gravitasi dan Pola Struktur Geologi, Proc PIT HAGI XXIII: 66- 72 
Nistor, M.M. \& Nicula A.S. (2021) Application of GIS Technology for Tourism Flow Modelling in the United Kingdom, Geographia Technica, Vol. 16, Issue 1, 2021, pp 1 to 12, DOI: 10.21163/GT_2021.161.01

Puspitasari, P., Rahatmawati, I. (2017) Mapping Potensi Wisata dalam Upaya Tata Kelola Green Ecotourism di Kabupaten Kaimana, Provinsi Papua Barat, Indonesia, Proc. Seminar Nasional \& Call for Paper in conjuction with 59 years of the faculty of Economics and Business, UPN "Veteran" Yogyakarta

Rahatmawati, I., Kusumayudha, S.B., Prastistho, B., Setyaningrum, T., Zakaria, M.F., Priyandhita, N. (2020)

The Intention to Repeat Visit Tourist Visits on The Geotourism Object of Cave Bentar, Tanjungsari, Gunungkidul, Yogyakarta, Indonesia, Journal of Environmental Management and Tourism, Vol 11 No 8, pp 1931-1937, doi: https://doi.org/10.14505/jemt.v11.8(48).00

Ruda, A. (2016) Exploring Tourism Possibilities using GIS-Based Spatial Association Methods, Geographia Technica, Vol. 11, Issue 2, 2016, pp 87 to 101, DOI: 10.21163/GT_2016.112.09

Setyaningrum, T., Rahatmawati, I., Kusumayudha, S.B., Prastistho, B., Zakaria, M.F. (2020) Geo Eko-wisata

Gua Tanjungsari (Cave Geo Eco-tourism of Tanjungasri), LPPM UPN "Veteran” Yogyakarta

Suyoto (1994) Sekuen Stratigrafi Karbonat Gunungsewu, Proc IAGI Annual Meeting XXIII, Vol I: 67-76

Van Bemmelen, R..W., (1949). The Geology of Indonesia, Vol. IA, Gov. Print. Office, The Hague Martinus Nijhoff.

https://notaclueadventures.com/2015/03/blog/ecotourism-vs-geotourism 